\title{
INFLUENCE OF PEER-TO-PEER-BASED EXCHANGE ON CREATING NEW BUSINESS MODELS
}

\author{
Jelena Stanković, \\ Ninela Kordić, \\ Slavka Drašković
}

Singidunum University, Belgrade, Serbia

Correspondence:

Ninela Kordić

e-mail:

nkordic@singidunum.ac.rs

\begin{abstract}
:
One-to-one communication and business concepts which emerged in the period of introducing information and communications technologies (ICTs) in business in the dawn of the New Economy of the early 2000, quickly shifted to "many-to-many" and further on to "peer-to-peer" exchange and collaborative consumption, pushed by the expansion of social networks, and the strong influence of economic and social factors. The sense of urgency as a result of rapid population growth and resource depletion provoked the need for establishing savvy business models that will support clever resource use by utilizing peer-to-peer exchange. Moreover, the purpose of this paper is also to present and analyze new business models which support collaborative consumption as an important alternative for reestablishing customers' trust and loyalty in organizations. Collaborative consumption as peer-topeer-based access to creation, production, distribution, consumption and trade of goods, services and information has become of high importance in business since it proved to bring lower costs of economic coordination within online communities, to speed up the pace of communication among reference groups of consumers, to contribute stronger communities, and to encourage sustainable development.
\end{abstract}

Key words:

collaborative consumption, economic factors, social factors, savvy business models, sustainable development.

\section{INTRODUCTION}

During the past twenty years, mass marketing has been replaced by „one-to-one“ marketing approach, based on individual communication with target customers (Peppers et al., 1999). Rapid use of information and communications technologies (ICTs) in business, enabled individual segmentation and building partner relationships with customers and clients (Rubin, 1997). Apart from ICT development, numerous market factors, especially economic and social factors escalated change in the way customers choose and consume products and services (Kotler \& Keller, 2012): the goods have become ,just a click away“ from the potential customers; balance of online and offline access to information and communication with providers of goods and services; „24x7x367“ has become the "code“ for location and convenience of purchasing products and services. Furthermore, the development of ICTs contributed to development of many-to-many marketing (Gummesson, 2006) as well as establishing social media as many-to-many communication platforms 
such as Facebook, Twitter, LinkedIn, followed by file sharing media (YouTube, Instagram), blogs, forums, and wikis. Based on that, the power of word-of-mouth (WOM) marketing has been empowered (Barak, 2016). The urge for establishing savvy business communication based on ITCs and personal characteristics of the existing and potential customers resulted in development of collaborative consumption and sharing economy, as a social and economic ecosystem built for the purpose of sharing human and physical resources in sense of common production, distribution, trade, and consumption of goods and services by different customers - individuals and organizations (Matofska, 2014). Economy of sharing has contributed to development of peer-to-peer (P2P) communication and exchange which has been present in all contemporary aspects of economic and social life.

\section{PEER-TO-PEER COMMUNICATION AND COLLABORATIVE CONSUMPTION- RESEARCH OVERVIEW}

Collaborative Consumption (CC) could be defined as "the peer-to-peer-based activity of obtaining, giving, or sharing the access to goods and services, coordinated through community-based online services"(Hamari et al., 2015, pp.1). CC projects are based on the use of online services which enable easy connection of individuals (peer-to-peer) and creating peer-to-peer networks.

Visual presentation of Collaborative Economy in Fig.1. displays the economy organized into various groups, sub-positions and example companies.

Authors Hamari, Sjoklint and Ukkonen (2015) expect that CC, as an economic and social category, will contribute to slowing down and decreasing some societal problems such as hyper-consumption, pollution, and poverty by lowering costs of economic coordination within communities. Rapid population growth and resource depletion provoked the need for establishing models which will enable access to and consumption of goods and services. Peer-to-peer exchange has proved to be the way to put up with the above-stated societal problems. The authors emphasize that there is actually a lack of information and deeper understanding of why people would participate in collaborative consumption. The research (Hamari et al., 2015) investigates customers' motivations to participate in collaborative consumption (CC). The study included 168 participants who were registered onto a CC site. It was discovered that the basic motivators are CC sustainability, personal enjoyment of the participants in the activities, and economic gains. In addition to that, the authors found out that people perceive the CC activity positively, but, at the same time, they

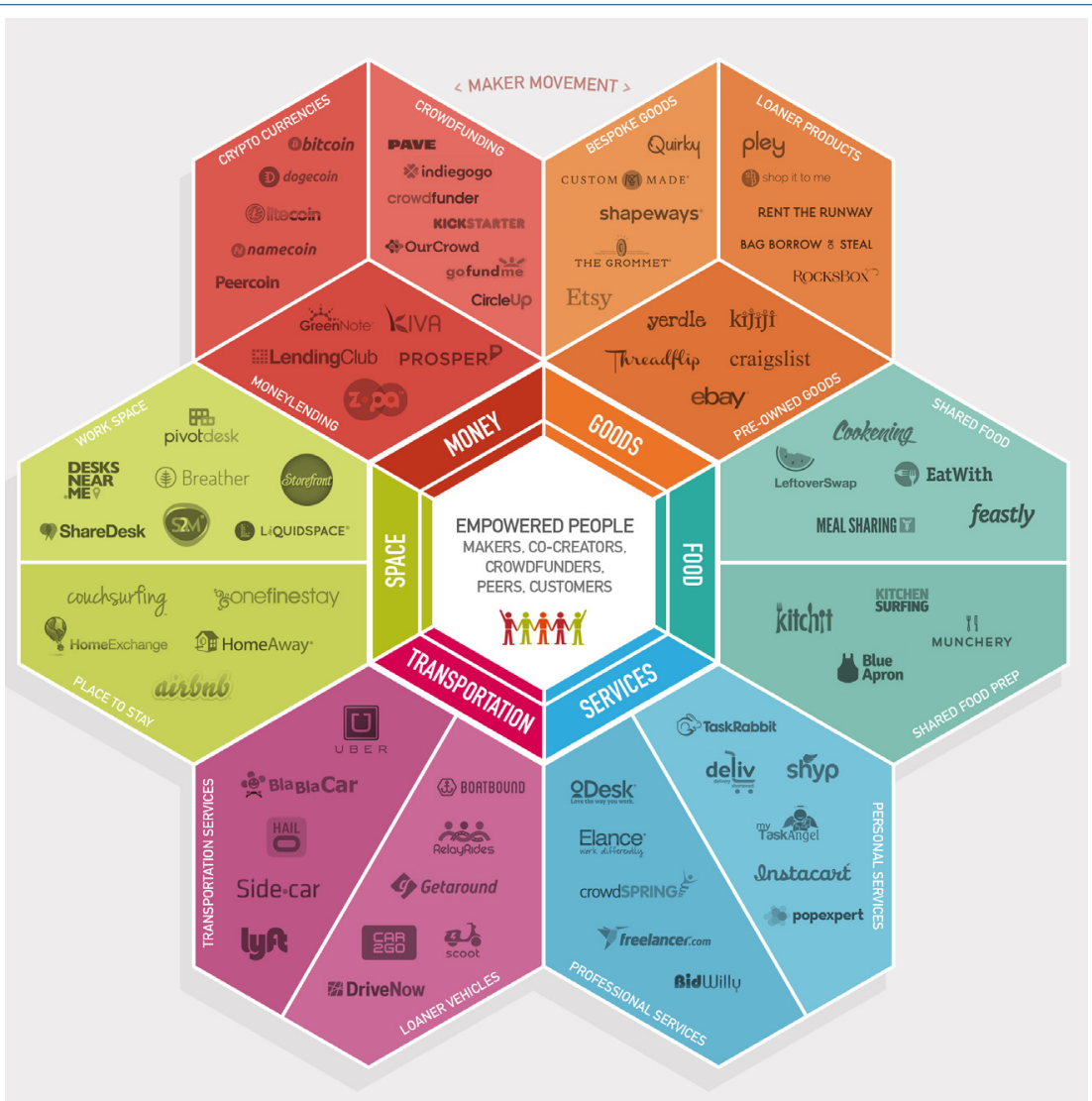

Figure 1. Collaborative Economy Honeycomb (Owying, 2014) 
do not necessarily translate their attitude toward offerings into real action (Hamari et al., 2015). The reason may be the lack of customers' understanding of the particular benefits of CC activities for them as participants, as well as for the society and the economy in general.

Another research (John, 2013) investigates the connection between CC and ICTs, in particular the internet, smart phones and social network sites (SNSs). The research included the analysis of 63 newspaper articles about CC, and argued that CC is a high-tech phenomenon which covers the main qualifications: (1) technology is described as the key driver of CC development; (2) technology is the driving force of CC, especially through use and development of social networks (e.g. Twitter and Face book); and (3) the terminology and metaphors used in CC can be easily connected with high-tech start-ups.

In 2010 Time magazine declared CC as one of the ideas with most potential to change business world (Walsh, 2010). CC has been included in some of the most popular services such as: AirBnB.com (space rental present in over 190 countries), FreeCycle.org (free exchange of presents and goods), Kiva.org (free lending money to alleviate poverty), Paperbackswap.com (free book exchange service).

According to Nielsen, in 2015 Airbnb was operating in more than 34,000 cities and 190 countries, with more than 25 million guests. Uber was available in 55 countries in the same year, with a presence in 150 cities in North America, 11 cities in Central and South America, 63 cities in Europe, Middle East and Africa, and 45 cities in Asia Pacific. Other services are only available in defined and smaller geographic areas, at least initially, such as onehour delivery by Amazon in some parts of New York city (Van Welsum, 2016). The rise of the sharing economy is displayed in graphic (Nielsen, 2014)

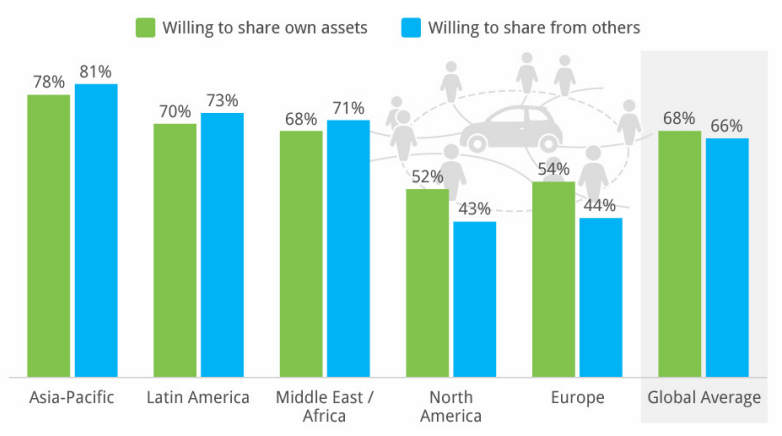

Figure 2. The Rise of Sharing Economy (Nielsen, 2014)

In his article in New York Times "Welcome to the 'Sharing Economy'“, Friedman (2013) explains the core of sharing economy based on the analysis of AirBnB.com i Vayable.com services. He concludes that the core of business change brought by CC and sharing economy is in building trust between companies and their customers. The purpose of CC and sharing economy can be seen in exchange of recommendations coming from the customers themselves (Friedman, 2013).

The development of sharing economy and peer-topeer exchange depends on people's willingness to share. According to Nielsen survey (2014), 28\% of global respondents stated positive when questioned about their willingness to share or rent their electronic devices for fee, $23 \%$ were willing to rent power tools, bicycles $(22 \%)$, clothing (22\%), household items (22\%), sports equipment (22\%), cars (21\%), outdoor camping gear (18\%), furniture (17\%), homes (15\%) motorcycles (13\%) and pets $(7 \%)$. When it comes to renting services, $26 \%$ of global respondents would rent lessons or services via the Internet, such as music lessons or dog sitting services.

\section{BUSINESS ASPECTS OF SHARING ECONOMY}

Sharing economy comprises different aspects of value sharing and creation in a way that economic, financial, ecological and social values are of equal importance. It also comprises alternative currencies, local currencies, time banks, etc., as a way of "giving and receiving" to build supportive networks, strong communities and social equity. Developing and accepting new business models based on collaborative consumption and peer-to-peer exchange can also contributes to clever and savvy use of disposable assets.

Sharing economy encompasses different structures such as for profit, non for profit, barter and cooperative structures (Friedman, 2013). Corporations, governments as well as individuals take active part in different evolving organizational structures acting as buyers, sellers, creditors or debtors (Altimeter Group, 2013).

Our planet and its inhabitants stand in the center of an economic system in which value creation, production and distribution should be in synergy and in sync with disposable natural resources. CC and sharing economy contribute to development of peer-to-peer exchange of information with the purpose of protecting resources, saving living costs, and reducing the risk of making wrong decisions in exchange with customers and users of similar goods and services (e.g. Neighborgoods.net service).

As the time passes by, the number of industries which accept sharing economy services is on the rise. One of 
the examples of sharing economy influence on classical economy is the increase of the number of web sites for fund raising (CrowdFunding), as well as the services for peer-to-peer lending such as Lending Club and Prosper (Berger, 2015). Such services have started to appear on the Serbian market.

Rachel Botsman (2010) points out that the mentioned development of trust by using peer-to-peer services will end up in creating a "currency" made up of reputation of the individuals and that will be used as a determinant for credit rating. In such a way, gaining trust in or/and of completely unknown people enables further development of CC and peer-to-peer exchange. From the individual measuring of influences of the individuals communicating on a distance, e.g. service Klout.com., researchers are now in the situation to classify the trust developed among distanced users as the key factor of success of the sharing economy projects conducted online and offline.

\section{SHARING ECONOMY AND BUSINESS MODELS BASED ON TRUST}

The analysis made in the European Union resulted in discovering new trends in business based on sharing economy, CC and peer-to-peer based communication and information exchange (Dervojeda et al., 2013).

As opposed to conventional business models which imply activities to enable customer's approach to assets of the company, peer-to-peer based business models enable customers to approach other customers' skills and competencies. Online platforms and online markets support connection of customers who own particular resources with customers who are in need of those resources.

The start-up companies are the first to be considered as the driving force of sharing economy (Dervojeda, 2013). Their role can be found in matching customers who own particular resources, such as competencies, skills or know-how, with customers who are in need of such resources, in right moment and with adequate transaction costs. Customers can also offer their own resources and look for demands and needs of other customers. Most of the start-up companies in sharing economy belong to incubator programs, in which they are advised how to provide startup capital.

The development of ICTs and the increase of web 2.0 enabled development of online platforms which promote user content, sharing and collaboration among users and customers, as well as database sharing (Kaplan \& Haenlein, 2010). There are also possibilities for peer-to-peer lending, such as platforms for micro lending e.g. Kiva, and crowd funding services e.g. Kick starter, one of the world's largest funding platforms for creative projects. It is interesting that within this platform, among others, exists the proposal for funding the local films by individuals from around the world (Kickstarter, 2016).

Open source software, online collaboration, database sharing and peer-to-peer lending are considered to be different activities of sharing economy, since they are based on ICTs and Internet support and improvements which have facilitated and simplified sharing physical and nonphysical goods (Hamari, 2015).

The are some important economic factors which stimulated development of sharing economy (Dervojeda et al., 2013):

- reduced customers' trust in business of the companies as a result of financial and economic crisis;

- increase of unemployment and decrease of purchasing power of customers which affected customers to develop the need to earn and save money.

The factors caused customers to be more sensitive to peer-to-peer business model, which are focused on customers and suppliers. In addition to that, the technology required for establishing and developing such models has become accessible at reasonable prices. The annual increase of sharing economy is estimated to be over $25 \%$ (Dervojeda et al., 2013).

One of the greatest challenges of peer-to-peer platforms from customers' perspective is the lack of trust in online transactions and activities in general. Therefore, the companies that operate in sharing economy try to increase trust by establishing peer-to-peer rating systems, identity authorizations, and quality and safety requirements (Dervojeda et al., 2013).

\section{INSTEAD OF CONCLUSION - CHALLENGES FOR SUSTAINABLE DEVELOPMENT AND PEER - TO - PEER EXCHANGE IN SERBIA}

The Commission of the European Union (EU) intensively analyses the effects of sharing economy on future personal, social, and economic development of its members (Mackay, 2015). Encouraging sustainable development should be one of the main goals, based on sharing economy development potentials which would be the following (Dervojeda et al., 2013) :

- decrease of negative influence to local environment - e.g. decrease in emission of carbon monoxide and reduction in use of natural resources, 
- build stronger communities, based on shared values and solutions,

- savings of lending cost and costs of raw material supply,

- help people use goods thay can not acquire easily,

- help creating minimal safety and quality standards for peer-to-peer markets,

- provide more training and education projects for programmers,

- make empleyment more flexible,

- help decreasing income taxes.

Based on previously mentioned, the examples of sustainable peer-to-peer activities can be found in Serbian economy. Peer-to-peer exchange services have been operating in Serbia for quite a while, although only a few of them are domestic. In June 2015, the first Serbian Car Sharing platform, Car4Use, started to operate. There are currently 57 active Car Sharing programs worldwide in all major cities. In all countries, other forms of transport are losing popularity, while the number of users of Car Sharing service is growing on a daily basis (Car4Use. com, 2015). Also, recent peer-to-peer project in Serbia is a platform whose establishment is underway and it should serve for exchanging goods and services in "helva“ as a currency (alva.rs). Unlike national currencies which are based on central or federal reserve or digital currencies (bitcoin - based on mathematical functions of computers), helva bases its value on human resources or number of established network among customers. Helva stands for accounting and exchange unit of goods and services. Personal profile of consumers includes personal identification and all transactions made. By now, helva is the only alternative currency in the region, while globally there are alternative currencies functioning locally in the similar manner (Otvorena škola ekonomije, 2014)

One should take into consideration the fact that some of the companies, involved in sharing economy, are being investigated. For instance, Uber is the company currently involved in several trials in Spain, France, Italy, Belgium and Hungary (Ashok, 2016). The company famous for lending flats and rooms, AirBnB, gets involved from time to time into legal prosecutions, based on complaints from associations of hotels. The General complaint is that AirBnB is involved in activities of disloyal competition and that more taxes should be paid for service they deal with (Tuttle, 2013).

Still, the greatest advantage of sharing economy and peer-to-peer transactions can be found in creating new jobs for people under thirty-five who are currently mostly unemployed. Also, peer-to-peer commercial transac- tions generate and encourage individuals to develop their skills that can be used in different industries which are important for developing more democratic economy and society (Dervojeda et al., 2013).

\section{REFERENCES}

Altimeter Group (2013). The Collaborative Economy. Retrieved March 2, 2016 from http://www.slideshare. net/Altimeter/the-collaborative-economy.

Ashok I. (2016). Uber shutdown demanded by Hyngarian taxi drivers, International Business Times, January 2016, Retrieved from http://www.ibtimes.co.uk/ uber-shutdown-demanded-by-hungarian-taxidrivers-1538745.

Barak, E. (2016). 3 Social Marketing Communication Methods: When \& How To Use Them. Retrieved March 3, 2016 from https://searchenginewatch. com/sew/how-to/2158216/social-marketing-communication-methods.

Berger, R. (2015). An investor's guide to peer-to-peer lending. Forbes. November 6, 2015. Retrieved March 10, 2016 from http://www.forbes.com/sites/robertberger/2015/11/06/an-investors-guide-to-peer-topeer-lending/\#68f811a59d48..

Botsman R. \& Rogers R. (2010). What's Mine Is Yours: The Rise of Collaborative Consumption. Tantor Media. Published September 2010. Retrieved March 5, 2016, from: http://www.goodreads.com/book/ show/9151984- what-s-mine-is-yours

Car4Use (2015). Car Sharing Company, Accessed March 20, 2016 from http://www.car4use.com

Dervojeda, K., Verzijl, D., Nagtegaal, F., Lengton, M., Elco Rouwmaat, Monfardini, E. \& Frideres, L. (2013). EC, The Sharing Economy, Accessibility Based Business Models for Peer-to-Peer Markets. Coordination: Directorate-General for Enterprise and Industry, Directorate B "Sustainable Growth and EU 2020", Unit B3 "Innovation Policy for Growth". European Union, September 2013.

Friedman L.T. (2013). Welcome to the 'Sharing Economy. Retrieved February 20, 2016 from http://www.nytimes.com/2013/07/21/opinion/sunday/friedmanwelcome-to-the-sharing-economy.html?_r $=0$.

Gummesson, E. (2006). Many-to-Many Marketing As Grand Theory: A Nordic School Contribution. In Lusch, Robert F. and Vargo, Stephen L. (Eds.), Toward a Service-Dominant Logic of Marketing: Dialog, Debate, and Directions. New York: M.E. Sharpe

Hamari, J., Sjoklint, M. \& Ukkonen, A. (2015). The Sharing Economy: Why People participate in collaborative consumption, Journal of the Association for Science and Technology. July 2015. Retrieved March 5, 2016 from http://dx.doi.org/10.2139/ssrn.2271971. 
John, N. (2013). Sharing, Collaborative Consumption and Web 2.0. Retrieved March 5, 2016 from http:// www.lse.ac.uk/media@lse/research/mediaWorkingPapers/pdf/EWP26-FINAL.pdf.

Kaplan, A.M., \& Haenlein, M. (2010). Users of the world, unite! The challenges and opportunities of Social Media. Business Horizons, 53(1), p. 59-68

Kikstarter (2016). Retrieved March 5, 2016 from: https:// www.kickstarter.com/projects/679582772/thugs-adocumentary-of-hooligans-politics-mafia-se, Feb 22016.

Kotler, P, Keller, K.L. (2012). Marketing Management. New Jersey: Pearson

Mackay C. (2015). "EU Commission to clarify stance on sharing economy", The Parliament Magazine, November, 9, retrieved March 5, 2016, from: https:// www.theparliamentmagazine.eu.

Matofska, B. (2014). The People Who Share, 'What is the Sharing Economy?' Retrieved March 8, 2016 from: http://www.thepeoplewhoshare.com/blog/what-isthe-sharing-economy/

Nielsen (2014). Is sharing a new buying, Reputation and Trust are emerging as new currencies, Retrieved March 2, 2016 from: http://www.nielsen.com/content/dam/nielsenglobal/apac/docs/reports/2014/ Nielsen-Global-Share-Community-Report.pdf.

Otvorena škola ekonomije (2014). Ideja alternativne valute-Alve,September 24, Retrieved from: http:// www.czkd.org/alternativne-valute-otvorena-skolaekonomije/.
Owying J. (2014). Collaborative Economy Honeycomb 1.0, Retrieved February 22, 2016 from: http://www. web-strategist.com/blog/2014/05/05/frameworkcollaborative-economy-honeycomb-osfest14/

Peppers, D., Rogers, M. \& Dorf, B. (1999.). The One to One Fieldbook: The Complete Toolkit for Implementing a 1 to 1 Marketing Program. New York NY: Currency Doubleday

Rubin, M., (1997.). Creating customer-oriented companies. Prism Arthur D. Little, fourth quarter

Tuttle B. (2013). The Other Complication for Airbnb and the Sharing Economy: Taxes, Retrieved. Time, Retrieved March 3, 2016 from: (http://business.time. com/2013/06/15/the-other-complication-forairbnb-and-the-sharing-economy-taxes/.

Van Welsum, D. (2016). Sharing is caring? Not quite. Some observations about 'the sharing economy', WB Group, Background Paper, Digital Dividends, Retrieved from: http://pubdocs.worldbank.org/ pubdocs/publicdoc/2016/1/308161452529903561/ WDR16-BP-Sharing-is-caring-DWELSUM.pdf.

Walsh B. (2010).Trend Alert! Collaborative Consumption, TOP 10 GREEN STORIES, Time Magazine. December 9, Retrived March 2, 2016 from: http:// content.time.com/time/specials/packages/article/0,28804,2035319_2034098_2034146,00.html. 